\title{
14. Police Leadership in Australia: Managing Networks
}

\author{
Jenny Fleming and Rob Hall
}

Organisations are bound up with the conditions of their environment. Indeed, it has been said that all organisations engage in activities which have as their logical conclusion adjustment to the environment (Hawley 1950: 3).

\section{Introduction}

There is a tendency in the police literature to attribute organisational activity and outcomes to individual action and specific internal factors (see, for example, Reiner 1991; Etter and Palmer 1995; Adlam 1998a, 1998b; Adlam and Villiers 2003; Haberfeld 2006). Relatively little of the police leadership literature focuses on the environmental context of organisations. Indeed, a recent entry in an international dictionary of policing on 'police leadership' refers to 'the varied nature of the interpersonal relationships between police managers and supervisors and the impact of these upon organisational performance'. The management of external environments is not considered in the entry (Bradley 2009). Such texts neglect the importance of political and social context and the external environment in which police leaders operate. No organisation operates in a vacuum. Perhaps we should not be surprised - the environment within which police work has changed significantly. Other studies of police leadership have also largely assumed the internal perspective with little reference to external activity. In 1991, Reiner's seminal work on police leaders in the UK identified leaders' 'main management problems' as relating to budgeting issues, internal communications, the increasing size of their organisations and the difficulties associated with meeting a variety of internal expectations (1991: 227-8). Similarly in Bradley, Walker and Wilkies' Managing the Police the emphasis is on 'managing within the police service' and there is no discussion at all of 'leadership' (1986: 3).

Today, internal issues are still important, but police organisations in Australia and elsewhere recognise that, to operate effectively, organisations must interact with their external environment and manage and steer the networks and the relationships successfully (Mitchell and Casey 2007: 201ff). As much of the public administration literature shows, a successful organisational leader is one that demonstrates 'the ability to cope with environmental contingencies; negotiating changes to ensure the continuation of needed resources'. Dealing only with internal adjustments, however effectively, will not guarantee 'survival of the 
organisation' (Pfeffer and Salancik 1978: 258). Police leadership now requires, in Rhodes' terms (1997: 57), a 'distinctive managerial style based on facilitation, accommodation and bargaining'.

This chapter considers these observations in the context of police leadership in Australia. It suggests that while internal management is important, strong and effective police leadership is increasingly about negotiating and managing the external and, in Emery and Trist's terms (1969), the often 'turbulent' and 'relatively uncertain' environment. It is about recognising the changing and dynamic nature of that environment, identifying the important actors and successfully interacting with those actors in an effort to maximise the control the leader has over his/her organisation and its resources. As well, it acknowledges the diverse nature of the governing structures within police organisations. After all, policing is also still about command and control regardless of the push for network activity (Fleming and Rhodes 2005). Creating the right balance within the organisation and minimising the impact of any potentially negative external elements on the organisation's resource base will be key roles for the police leader in the $21^{\text {st }}$ century.

We begin by providing a brief historical and institutional context for policing in Australia, demonstrating the traditional role of the police leader as working with and through their organisation with an emphasis on internal management. In the absence of any theoretical frameworks for police leadership we don public administration spectacles and draw on public administration literature to discuss public leadership and the management of external constituencies. Drawing on resource dependency theory, the chapter identifies a number of strategies open to organisations to manage inter-organisational dependence and the power of external environmental elements. We provide illustrative examples. The chapter argues that a critical role for police leaders is to identify and pursue strategies that allow them to negotiate and manage the overlapping networks that make up their external constituency as well manage the internal dynamics of the organisation.

\section{The Australian context of policing}

Australia comprises six States - Queensland; New South Wales (NSW); Victoria; Tasmania; South Australia (SA); and Western Australia (WA) and, for the purposes of policing, two Territories, the Australian Capital Territory (ACT) and the Northern Territory (NT). Each jurisdiction has a Police Commissioner (or in the case of the ACT, a Chief Police Officer) and its own government-administered police agency. The Australian Federal Police (AFP) is Australia's federal law enforcement agency. It provides a community policing service to the ACT government. With a national total of approximately 52,000 officers, the eight police forces range in size from NSW with almost 15,000 officers to the ACT with approximately 621 . 
Australian police organisations were shaped and consolidated in the mid-1850s in a colonial context, 'which gave them a specific political and administrative role' involved in a variety of duties. Over time police were formed into 'substantial bureaucratic organisations'. These highly centralised organisations were 'subject to the powerful authority of a single [Police] Commissioner, subject de jure to the direction of a responsible minister' (Finnane 1994: 29-30, 34). The following decades were characterised by the growing importance and political influence of the Police Commissioner, 'sustained by judicial and political affirmation of the relative independence and autonomy of police administrations in police affairs' (Finnane 1994: 31).

Over time, the formation of police unions (Finnane 1994: 44-51; Fleming and Marks 2004) and the increasing involvement of political figures in police operations (Fleming 2004) curtailed the Commissioner's autonomy and forced him to look beyond the four walls of his organisation. Prior to the 1980s, police organisations were structured on authoritarian, paramilitary lines and regulated through strict organisational rules and legislation. Recruitment, training, promotion and disciplinary processes were conducted internally and in line with administrative trends elsewhere. Police organisations were hierarchical, inwardly focused and conducted their business through the relevant police departments and their attendant bureaucracies (Fleming and Lafferty 2000).

New management techniques derived primarily from the private sector were introduced in the 1980s to restructure public sector agencies along broadly corporate lines. Administrative and police reform became a continuing activity for police organisations. Performance management regimes, new accountability mechanisms, external civilian review bodies, budgetary concerns and recruitment and retention strategies became central issues for the police leader. The external environment had also changed. A new focus on community policing, with its emphasis on working with communities to identify problems and solutions, was an example of such change. Communities were now consumers or clients and educated to expect a particular level of service. A number of mechanisms were put in place whereby community satisfaction with police services was monitored regularly, resulting in a more outwardly focused pro-active emphasis on police practice (Fleming and O'Reilly 2007).

The political salience of domestic law and order issues and the perceived threat of terrorism activities have become part of the everyday discourse of politics (and indeed the media). Once part of every bureaucratic decision and change, police commissioners are now part of a rapidly changing world where delegation is the order of the day and they are assessed as much for their ability to manage their external constituencies - and to operate effectively in a public arena - as they are for their internal management skills. 
Slowly, Australian police organisations have broadened their horizons and have acknowledged the changing environment in which they are now expected to operate. The traditional closed and insular nature of police organisations, committed essentially to managing the internal components of the organisation, has given way to a stronger focus on external constituencies. The 'tell 'em nothing era' (Munday 1995) has faltered under the gaze of an increasingly intrusive media and self-aware communities who demand to be informed and consulted about the way police do business. Every jurisdiction now has a media director and media department. As MacDonald has commented, such a level of scrutiny ensures that every comment or decision made by a police leader has the potential to become part of a public debate. As he points out, 'Today, policing is everybody's business' (1995: 220-1). The police leadership role is shaped accordingly. The following section turns to the issue of leadership and the increasing need to interact with other organisations in an effort to manage resources and minimise the impact of external elements.

\section{Public leadership and external constituencies}

Storey (2004: 23-5) cites the importance of big picture sense-making (i.e. the ability to scan and interpret the environment; to identify threats to and opportunities for the organisation; and to assess the strengths and weaknesses of the organisation); the ability to deliver change and inter-organisational representation (involving skills such as coalition-building, understanding others' perspectives, persuasion and the assessment of client needs) as crucial elements of good leadership.

While we acknowledge the significance of these capabilities, we would add that such behavioural attributes are much broader than he sketches and more literally embodies Allison's (1982: 17) 'external constituencies'. These include, dealing with external units of the organisation and dealing with independent organisations such as other public sector agencies, interest groups, the private and voluntary sectors, the public, and the media. In other words, engaging in external network activity and developing strategies to steer and manage those networks. Ferlie and Pettigrew's work has shown that public sector managers are increasingly looking to the external environment. In their study of network management in the British National Health System (1996: 88-9), Ferlie and Pettigrew's CEOs felt themselves to be highly 'outward facing' and believed that it was crucial to institutionalise strategic alliances by fostering a shift from reliance on interpersonal trust to a deeper inter-organisational trust (Ferlie and Pettigrew 1996: 88-9). How then to achieve such focus?

A resource dependence perspective, based on the seminal work of Thompson (1967), Elkin (1975), Pfeffer and Salancik (1978) and Rhodes (1997) provides insights into what this 'outward facing' leadership of network management entails. This perspective starts from the premise that, to survive, organisations 
require resources. The acquisition of these resources typically means that the organisation must interact with others who control them. Control over required resources provides those who control them with power over the organisation. It follows, then, that managing relations with networks of interdependence is the focus of much organisational attention and activity. In the following section we identify a number of strategies available to organisations to manage dependence: the development and maintenance of alternative sources of needed resources; the acquisition of prestige; contracting or bargaining; penetration; knowledge-driven strategies; and the socialisation of conflict. It is not an exhaustive list. It provides a context for us to frame the increasingly outward focus of Australian police leaders

\section{Network management by Australian police leaders}

Managers and, for our purpose, police leaders can seek to minimise the power of external environmental elements over them by adopting a number of strategies (see for example, Kickert et al. 1997; Perri 6 et al. 2002). Thompson (1967: 32-3) refers to competitive strategies, one example of which is the development and maintenance of alternative sources of needed resources. The recruitment of police officers from a relatively small pool has meant that finding alternative sources has been a preoccupation for Australian police leaders.

In the face of unusually high attrition rates, many Australian police organisations have, in recent years, needed to negotiate the difficulties of recruiting police officers. The lack of suitable applicants has been compounded by a number of issues. The AFP's continued involvement with international deployment activity has seen the secondment of several state and territory officers to overseas postings indefinitely. The growth of the AFP's national counter-terrorism activities in Australia has required a significant increase in specialist personnel. It is common knowledge that the AFP is successfully enticing such specialist staff from the States and Territories. Rather than relying on poaching officers from other Australian jurisdictions and/or hoping for an increase in interested parties, many States are now competing against each other in the quest for recruits. Most jurisdictions are looking carefully at alternative recruitment sources. Strong economic booms in Queensland and Western Australia (WA) have seen many officers abandon policing for lucrative jobs in the States' mining industries. At the present time, WA Police is competing with jurisdictions, not only in Australia but also in the United Kingdom, to recruit British police officers. In the past year, South Australian police leaders have successfully recruited over 200 trained officers from Britain.

Acquiring prestige is another important competitive strategy. As Thompson notes (1967: 33), 'Acquiring prestige is the "cheapest" way of acquiring power'. It is a strategy whereby organisations create and maintain a 'favourable image of the organisation in its salient publics'. This is crucial when support from 
external constituencies is required to control, or reduce dependency. Prestige is acquired in a number of ways, most obviously in the representative role of the Commissioner.

The representative role of police leaders is now an accepted part of a police leader's portfolio. An examination of one police leader's diaries reveal that the external representative role in the years 2001-05 took up almost $60 \%$ of the Commissioner's working time. Apart from extensive engagement with the media over this period the interactive role includes formal meetings with the Police Minister, meetings with other government figures (including opposition members), meetings with the Ombudsman, working on external committees, parliamentary estimate hearings, liaising with the police union and various other activities that involve working closely with a variety of external organisations and networks. By far the more time-consuming work is the Commissioner's 'community role'. Official ceremonies, invited speeches and attending social gatherings as 'Commissioner' takes up the bulk of the external constituency work. The work is regarded as crucial in maintaining the organisation's positive and prestigious profile in the community. ${ }^{1}$

Cooperative strategies - or tactics as Perri 6 et al. (2002: 126) refer to them are increasingly utilised by police leaders. Thomson talks about contracting or bargaining (Thompson 1967: 34-6). Elkin (1975: 175) refers to 'exchange' whereby an organisation may negotiate a deal with another organisation on which it may depend for resources. In Australia, the police union movement is active, politically manipulative and not reluctant to flex its industrial muscle where necessary (Fleming and Marks 2004). The organisations are staffed by professional industrial advocates and non-police personnel. Working police officers form an executive which oversees activities. The organisations have significant amounts of money and are a formidable external presence for Australian police organisations. In most jurisdictions the unions enjoy almost 100\% membership. Most police leaders have, in recent years, been required to bargain either in a formal industrial relations context with their respective unions or in a more public setting where unions are threatening to withdraw resources if their needs or demands are not met. Such scenarios have, in recent years, become quite common in specific States. The degree to which the police organisation has been able to develop 'a favourable image ... in its salient publics' is often important in the context of community support and also when bargaining situations have to be negotiated by third parties (Fleming and Lafferty 2001).

Another cooperative strategy is that of penetration (Elkin 1975: 175), whereby an organisation places its own personnel into the organisation in which it is dependent. Two short examples illustrate the point. As national security and technological crime become a central focus for police organisations, knowledge becomes an important commodity. Many organisations seek out the information 
by placing their own personnel into organisations that have this information. So for example, senior officers in Australia have been seconded to the nation's airline in order to understand and develop strategies around aviation security. Similarly, technological challenges for police have meant close ties with computer technology organisations as together they seek to curtail the rising levels of cybercrime.

Knowledge-driven strategies or tactics are defined by Perri et al. (2002: 127) as those which seek to create a 'specialist structure for knowledge creating and sharing'. In Elkin's terms this could also be referred to as 'penetration'. The emphasis in Australia on police professionalism, tertiary education and the importance of evidence-based research in policing has led to all jurisdictions collaborating with universities and other knowledge based institutions to deliver education and training services and to engage in research that will inform police policy and practice. We now talk about 'police research networks' (Bradley et al 2006).

Illustrating this strategy further is the recent establishment of the Australia and New Zealand Policing Advisory Agency (ANZPAA). In an effort to provide stronger support to police commissioners and collaborate effectively across the jurisdictions, Australian police commissioners have brought together 17 agencies previously committed to research, policy advice, training and education initiatives and a variety of police advisory forums to form a cross-jurisdictional organisation. ANZPAA is staffed by police personnel and trained researchers and the emphasis is on knowledge-management and information sharing. ANZPAA's role will be to develop research and policy and provide strategic advice and support to the Australian and New Zealand Police Commissioners. This knowledge-driven strategy allows for a range of occupational experts, researchers and consultants to engage in advocacy to build an environment and culture, in which police commissioners can direct their resources to attaining knowledge they require and in the format they prefer, rather than relying solely on university researchers, monitoring databases and official state statistics for their information. Such a prestigious organisation will assist in facilitating information sharing across a variety of organisations and will assist in building and sharing information with those among whom they seek integration (Perri 6 et al. 2002: 126-7). Such a structure has created a 'specialist structure for knowledge creating and sharing'. It also allows police commissioners to identify their favoured research areas and control the dissemination of the findings.

A final example can be identified using Elkin's discussion of the 'socialisation of conflict' whereby the focal organisation attempts to involve other actors in a particular issue in order to broaden the scope of discussion and/or possibilities in an attempt to alter the balance of opinion and resources confronting the organisation (Elkin 1975: 173-5). 
In July 2007, following a suicide attack at Glasgow airport in Scotland, the AFP apprehended Dr Haneef trying to leave Australia. He was held without charge under new laws that allowed terrorism suspects to be detained indefinitely without questioning. The charges were dropped soon after, although his working visa was revoked on 'character grounds'. A political controversy arose around immigration policy and the extent to which the AFP had played into the hands of a government seeking to impose its anti-terrorist policies ahead of an imminent federal election. The media focus compelled everyone involved to seek mitigating circumstances for their actions.

The Director of Public Prosecutions (DPP) admitted to mistakes, blaming an 'over-worked prosecutor for undue haste'. The AFP Commissioner's strategy was to deflect effectively the onus of responsibility by pointing the finger elsewhere. Despite discrepancies in the interview process (the transcript of which was made public by Haneef's lawyers) and a court affidavit, and despite the British authorities disputing the AFP's account of the affair, the AFP response was to widen the scope of conflict.

In the first instance, the AFP Commissioner made formal complaints to the Legal Services Commission about Haneef's legal team releasing information to the media during an inquiry. Effectively such an action meant that the lawyer in question could be struck off the Register of Barristers. Such a strategy ensured front-page headlines and high profile debate. The Commissioner publicly refuted the way in which Australian courts operated, arguing that, 'The courts ... are going to need to change the way they view evidence, witnesses and forensics'. His railing against the 'court of public opinion' and the irresponsible media 'hampering the efforts of police' was widely reported in the media. The Commissioner's allegations that he had advised the DPP that the evidence was weak, but that 'the police were obliged to charge Haneef on the prosecutor's advice' was also widely reported. Despite the obvious blunderings of the organisation, his assertions to a Senate Committee hearing that there was no need for the AFP to 'alter our policies or alter our approaches' compounded the organisation's efforts to widen the scope of conflict in the political arena.

By altering the balance of opinion in the public arena and diluting the onus of responsibility, the AFP Commissioner had effectively in, Elkin's terms, 'socialised the conflict'. While many media outlets commented on the Commissioner's attitude that 'everyone was to blame but him,' the strategy was successful. At one point it looked like the Commissioner would lose his job but the moment passed as 'ongoing inquiries' have served to defer a conclusion to the affair.

These examples have sought to demonstrate the way in which police organisations can manage dependence and minimise the power of external environmental elements. Such strategies are not mutually exclusive. For example, the AFP and its standing in the community (a standing that the AFP and its public relations 
department work on fervently) was frequently commented on in the media at the same time it was vilifying the organisation's behaviour in the Haneef case. The prestige of the organisation became a mitigating factor that the AFP could fall back on in the face of a barrage of external criticism.

\section{Conclusions}

Elkin notes (1975: 175-6) that while one actor in the network may be engaged in one or more of these strategies, others are similarly engaged. As a result there is a complex dynamic at work, 'there are multiple, overlapping relationships, each one of which is, to a greater or lesser degree, dependent on the state of the others'. It is in recognising this complex dynamic and identifying the most appropriate strategy to achieve a specific objective that the police leader will demonstrate to what extent he/she has developed a skill set for managing networks. And the stakes can be high. Coping with external contingencies and constraints is critical to organisational effectiveness and, in many cases, survival. As Pfeffer and Salancik (1978: 137) succinctly put it, when external demands cannot be met because of constraints on the organisation, the leader can be removed: the replacement of the leader, who has come to symbolise the organisation to various groups, may well be sufficient to relieve pressures on the organisation. Or, as noted above, strategies to manage dependence and conflict may well save the day.

Police leadership is fraught with difficulty. The modern Australasian policing environment is increasingly complex and challenging. Changing demographic, social, and economic conditions; transnational crime, terrorism, peacekeeping and international deployments have served to broaden the focus of police leaders. Law and order was always a political minefield and continues to be so. New and emerging technologies have transformed the nature of crime and the manner in which police respond to it. Traditional police tasks such as finger printing and escorting prisoners to court are now outsourced by many organisations. Meeting community expectations, providing a visible presence and working with a variety of stakeholders to identify and solve problems is resource intensive. Such complex changes require police leaders to look forward and outward to ensure that they have the capacity to anticipate and manage resource dependency and the external environment.

This complex and ever changing environment raises a number of issues for police governance. Traditionally, police leaders in Australia were autonomous and answerable only to the department. They ran tight, authoritarian organisations that were essentially inwardly focused. Today, command and control is still the dominant governing structure in police organisations but the external environment requires more flexibility than this structure allows. The importance of working with communities and connecting with external constituencies is crucial. In doing so new governing structures with an emphasis on networks 
and partnerships have come to shape and determine many aspects of the police leader's role. But, as Fleming and Rhodes have noted (2005: 203), 'the cooperative behaviour of a network can collapse under the impact of competition or of changed priorities'. Ensuring the capacity of the organisation for command and control responses while at the same time maintaining the fine balance of an inter-dependent network, managing dependence and the external influence of organisations is a primary focus for today's police leader. In some ways it may well be regarded as what Mark Moore has termed an 'impossible job' (1990: 72).

\section{References}

Adlam, R., 1998a, 'Uncovering the "ethical profile" of police managers and the "moral ethos" of police organisations: A preliminary study', International Journal of Police Science and Management, 1:2, pp. 162-83.

Adlam, R., 1998b, 'What should we expect from police leaders?' Police Research and Management, Spring, pp. 17-30.

Adlam, R. and P. Villiers, 2002, Police Leadership in the Twenty-first Century: Philosophy, Doctrine and Developments, Winchester: Waterside Press.

Allison,Jr. G. T., 1982, 'Public and Private Management: Are they fundamentally alike in all unimportant respects?', in F. S. Lane (ed) Current Issues in Public Administration, 2nd edition, New: York: St Martin's Press, pp. 13-33

Bradley, D., 2009, 'Police Leadership', in A. Wakefield and J. Fleming (eds), The Sage Dictionary of Policing, London: Sage Publishing (forthcoming).

Bradley, D., C. Nixon and M. Marks, 2006, 'What works, what doesn't work and what looks promising in police research networks', in J. Fleming and J. Wood (eds) Fighting Crime Together: The Challenges of Policing and Security Networks, Sydney: University of New South Wales Press, pp. 170-94.

Bradley, D., N. Walker and R. Wilkie, 1986, Managing the Police: Law, Organisation and Democracy, Sussex: Harvester Press.

Elkin, S. L., 1975, 'Comparative urban politics and interorganisational behaviour', in K. Young (ed) Essays on the Study of Urban Politics, London: MacMillan Press, pp. 158-184.

Emery, F. E. and E. L. Trist, 1969, 'The causal texture of organizational environments', in F. E. Emery (ed) Systems Thinking, Harmondsworth: Penguin, pp. 241-57.

Etter, B. and M. Palmer, 1995, Police Leadership in Australasia, Leichhardt: Federation Press. 
Ferlie, E. and A. Pettigrew, 1996, 'Managing through networks: Some issues and implications for the NHS', British Journal of Management, 7, pp. 81-99.

Finnane, M., 1994, Police and Government: Histories of Policing and in Australia, Oxford: Oxford University Press.

Fleming, J., 2004a, 'Les liaisons dangereuses: Relations between police commissioners and their political masters', Australian Journal of Public Administration, 63:3, pp. 60-74.

Fleming, J., 2004b, 'Commissioner Mick Keelty, Australian Federal Police', Police Practice and Research, an International Journal, 5:4/5, pp. 317-26.

Fleming, J. and G. Lafferty, 2000, 'New management techniques and restructuring in police organisations', Policing: An International Journal of Police Strategy and Management, 23:2, pp. 154-168.

Fleming, J. and G. Lafferty, 2001, 'Police Unions, Industrial Strategies and Political Influence: Some Recent History', International Journal of Employment Studies, 9:2, pp. 131-40.

Fleming, J. and M. Marks, 2004, 'Reformers or Resisters? The State of Police Unionism in Australia', Employment Relations Record, 4:1, pp.

Fleming, J. and J. O'Reilly, 2007, 'The small-scale initiative: The rhetoric and the reality of community policing in Australia', Policing: A Journal of Policy and Practice, 1:2, pp. 1-8.

Fleming, J. and R. A. W. Rhodes, 2005, 'Bureaucracy, Contracts and Networks: The Unholy Trinity and the Police', Australian and New Zealand Journal of Criminology, 38:2, pp. 192-205.

Haberfeld, M. R., 2006, Police Leadership, New Jersey: Pearson Prentice Hall.

Hawley, A. H., 1950, Human Ecology, New York: Ronald Press.

Kickert, W. J. M., Klijn, E. H. and J. F. M. Koppenjan (eds), 1997, Managing Complex Nnetworks: Strategies for the Public Sector, London: Sage Publications.

MacDonald, R., 1995, 'Skills and Qualities required of police leaders, now and in the future', in B. Etter and M. Palmer (eds), Police Leadership in Australasia, Leichhardt, Federation Press, pp. 208-233.

Mitchell, M. and J. Casey (eds), 2007, Police Leadership and Management, Leichhardt: Federation Press.

Moore, M. H., 1990, 'Police leadership: The impossible dream?' in E. C. Hargrove and J. C. Glidewell (eds) Impossible Jobs in Public Management, Kansas: University Press of Kansas, pp. 72-102. 
Munday, J., 1995, 'You can run, but you can't hide — dealing with the media, for chief executives' in B. Etter and M. Palmer (eds), Police Leadership in Australasia, Leichhardt, Federation Press, pp. 256-77.

Perri 6, D. Leat, K. Seltzer and G. Stoker, 2002, Towards Holistic Governance: The New Reform Agenda, Hampshire: Palgrave.

Pfeffer, J and G. Salancik, 1978, The External Control of Organisations: A Resource Dependence Perspective, New York: Harper and Row.

Reiner, R., 1991, Chief Constables - Bosses, Bobbies or Bureaucrats? Oxford: Oxford University Press.

Rhodes, R. A. W., 1997, Understanding Governance. Buckingham: Open University Press.

Storey, J., 2004, 'Changing theories of leadership and leadership development', in J. Storey (ed), Leadership in Organisations: Current Issues and Key Trends, London: Routledge, pp. 11-37.

Thompson, J. D, 1967, Organisations in Action, New York: McGraw Hill.

\section{ENDNOTES}

1 Research in progress by Fleming. 